\title{
İdare Hukukumuza Genel Bir Bakış
}

\author{
Yazan: Ord. Prof. Vasfi Raşit SEvtG
}

Dünya büyük, pek büyük buhranlarından birini daha yașıyor. Hiç bir buhranın çözüm tarzı olamamış olan silâh, içinde bulunduğumuz ve çok derin sebeplere dayanan buhranin da çözüm tarzı olamıacaktır. Hiç bir harp, hiç bir andlașma hiç bir meseleyi kesin bir çözüme ulaştırmamış ve her harp gelecek bir harbe meşime (son) olmuştur. Kuvvetlerin bir andaki tevazününün ifadesi olan andlașmaların çoğu yeni bir harbin ateș ve kan tufanı arasında eriyip gitmiştir. Atatürk'ümüz «Büyüik hadiseler, büyük inkilâplar (dévrimler) yaratır» der; içinde yașadığımız büyük hadiseler cemiyet âdetlerini, hükümet ve firka kavramlarını, sosyal terbiye tarzlarını altüst eden büyük devrimler doğurmaktadır. Devrimlerin talii ise, silâhların daima değișen ve er meydanlarının deniz ve dalgaları gibi daima oynak olan talilerine asla bağlı değildir. Birinci cihan harbini takibeden ve hacmi, yangınları gibi zamanımızin ufuklarına s1ğışmayan büyük devrimler 1939 dan itibaren harp şeklini aldı; çok yakın gelecekte gene yüzlerine sulh nikabını geçirebilirler; fakat yokolamazlar ve yokedilemezler. Bu derin hakikatlara vakıf olanlar selâmeti ne silâhların taliinden, ne iflâs eylemiş olan muvazene siyasetinden ne de dörtler idaresinden beklemiyorlar. Selâmeti hacim ve șümulleri millî hudutları ve zaman çerçevesini aşan davaların «aynı paydaya» getirilmesinden eski tabirimizle mahreçlerin birleştirilmesinden umuyorlar. Demokrasi de -ki kapitalizmin siyasî ifadesidir-, sosyalizm de ve daha sair cereyanlar da hepsi dünyayı saran buhranların birer çarpanıdır. Bu çarpanlar aynı paydaya getirilmedikçe güç olan sulh işlemi yapılamaz Sulh ișlemi yapılamayınca devrim dalgaları yatışmaz. Yatıșmayan bu dalgalar memleketleri sarsintısı içinde tutar.

Hakikî dalgalar gibi önüne çıkan her seddi yıkan inkilâp dalgalarının yalnız ve yalnız büyük idarecilerle büyük hukukçuların eseri olan idare seddini yıkabilmiş olduğu șimdiye kadar görülmemiștir. Halk kabarmaları ve tașmaları tekrar ediyorum, yalnız ve yalnız büyük idareci- 
lerle büyük hukukçuların eseri olan idareye kadar ulaşamıyor ve yükselemiyor. Hatta her șeyi yıkan ve zayıflatan devrim yalnız idareyi yıkamiyor ve onu tersine olarak büyütüyor, kuvvetlendiriyor. Çünkü devrim gerçekleştirilecek bir politikadır. Politika yalnız idare ile gerçekleștirilir ve idarenin biricik konusu olur. Idare bir âlettir. İdaresiz ne devrim ne de politika olabilir. İdareden mahrum bir devrim kötü bir rüyadan bașka bir șey değildir, idareyi elinde tutan kazanır. Bunun içindir ki sunulan yenilikleri kabul etmiyenlerin elinde kalmıș idare XX nci asrın içinde bulunduğumuz ilk yarısında çıkmış bütün korkunç buhranlara karşı koyabilmiş biricik kuvvet olmuştur. Türkiye'mizde bile saltanat ve İstanbul hükümetleri yıkılıp silindiği zaman devrimin eline geçen idare intizam ve kuvvetini kaybeylemiş memleketin, saltanat rejiminden cumhuriyet rejimine sarsintısiz bir surette geçmesini mümkün kllmıștir; bütün hercümerçlere rağmen intizam ve asayiși muhafaza eylemiştir. Bu hadise bile bașlı bașına düșünenlerin ve devlet j̇dare edenlerin dikkat nazarını çekmeğe kâfi gelir. Osmanlr idaresinin istibdat réjiminin tazyiklerine, hükümdarların keyif ve heveslerine, istilâlar; millî mücadelenin ilk anlarındaki mukavemet tarzını teșkil eden çete Häreketlerine ve doğurduğu isyanların ihtiyaçlarına nasıl karşı koyabiliniss olduğunu; bu kadar çeșitli siyasî hallerin zaruretlerine nasıl intibak ettiğini araștirmak bile faideden hali değildir. Bu kadar zit kuvvetlere hakim olmak ve memleketin ruhunun derinliklerine kadar intizam, disiplin ve iffetin zevk ve adedini sindirmek kudreti ancak ve ancak idareye hâs bulunan bir kuvvettir. Fakat unutmamalı ki bu ödevini bașaramìyan yani intizam, disiplin, iffet ve doğruluğun zevkini tattiramıan, ètriniyet telkin etmeyen bir idare istilâ ordularının vücude getiremiyereği çöküntüyü vücude getirir.

-. Hudut ve șumulü iyi tayin ve tašrih edilmiş bir hiyerași (müratebe) memleket idaresine başlica esastır. Devletin memursuz ve memuriyetsiz idaresíne imkân yoktur. Her hükümet ve hükümdar hudutsuz kudrete ancak maiyetinin hareketlerini bir intizam altına almakla, adaleti, kolluku (inzibatı) ve içtimaî uzviyetin diğer görevlerini hakkile tevzin etmekle ehliyet kazanir ve malik olur. Osmanl İmparatorluğu hükümdar ve hükümetine o sınır kabul etmeyen kuvveti her çeșit devlet hizmetlerini tanzim etmek, her birinin vazifesini, hatta kılığinı tayin etmek suretiyle verebilmiștir. Hiç bir șey tesadüfe bırakılmamıș ve Osmanlı teşkilâtı (kuruluşu) tâbiri ile anılan o muazzam makinenin bütün parçaları hakimiyet ve kuvvet çarhlärinı harekete getirebilecek bir kaabiliyette olarak telif edilmiști. Teşkilât yani idare, șebekesini o geniş imparatorluğun her tarafına yaymıș ve en kudretli bir merkeziyete vücut $\mathrm{v} \wedge \mathrm{r}$ - 
miști. Coğrafya istilahları arasında yine yeri olmıyan «Osmanłı» tâbiri ne bir memleketin ne de bir halkın adıdır. Birleştirilmiș memleketlerin ve birleştirilmiș halkların kilit tașının adıdır. Bir çok memleketlerin, bir çok kalelerin bir çok eyaletlerin birleșmesinin tașıdığ 1 isimdir: Müșterek bir idarenin ifadesidir. Osmanl tahtının sahibi olmuş sultanların hiç biri hiç bir fermanda Osmanlı ülkesinin sahibi ve hakanı olduğunu söylemez; o birleșik ülkeyi kısımları ile anar. Bu ülkeler yığını bir muvazeneye ihtiyaç gösteriyordu. Kuvvetli bir kurulușa yani idareye malik tek bir hükümdar tarafından idare edilen devlette muvazene bir hakikat idi ve bu hakikat anayasa yerine geçiyordu. İdare ve ordu ayni mahiyette uzuvlardır. İkisi de hükümetin politikasını --biri sınırlar içinde diğeri sinurlar ötesinde- gerçekleștirir.

Osmanlı devleti, idaresinin her gün halka müsavat dairesinde dağıttığı refah, güven ve hususile adalet ile büyüyordu. Böylece yüklenilmesi güç olan o heybetli idarenin ezici ağırlığını halk duymuyordu. Oșmanlı idaresi, tabiiyeti altına aldığı halk için; uğruna savaștıkları hürriyetlerinin kayıbından doğan a'cılarıia bir teselli kaynağı teşkil edjyorơu. Halkın refah seviyesini yükselten Osmanlı idaresi, mağlûp milletlere kendi beylerinde bulamamıș oldukları bir şefkat ve adaleti temin ediyordu. Bir nizam ve intizam altında idare edilen eyaletlerde, halk rayalığın sevecek kađar bir refah ve emniyete kavuşmuștu. Yer yer isyanların ve istilâların tamamiyle yıkamadığı bu kudretli idare isyan ve istilâlara, sultanların çlgınlıklarına, vezirlerin irtikâp ve irtikalarına ve 0 muazzam yapıyı yavaș yavaş kemiren bütün fenalıklara asırlar boyunca kar\$1 koyduktan sonra, Osmanlı imparatorluğunu batıran ve Nizip vakasında en had devresine giren felâketlerle birlikte silinip gitti.

Idare insanın iç azalarına benzer; lüzumları inkâr edilmiyen bu azalar hissedilmemelidir. Hissedilmeleri hastalıklarına ve görevlerini görmez olmalarına delâlet eder. Görevini göremiyen bozulmuș idare memleketi bir karın ağrısı sancıları arasında yașatır. Otorite sevdasına düșmüș hükümetlerinin zaaflarını, milleti sancılar içinde yaşatmak gayretleri vücude getirir. Hükûmet ödevlerinin otoritesiz olarak görülmesine imkân olmadığı muhakkaktır; bu sebepten otorite herkesin arzusudur. Anadolu köylüsü otoriteden mahrum bir hükümeti evde kạrisına söz geçiremeyen bir erkeğe benzetir. Devletin yapacağı vazifeler vardir ve bu vazifeleri yerine getirebilmesi için insanlara emretmeğe, mecburdur. Otorite devletin emretmek yetkisinin ifadesidir. Hürriyet ise insanin devlete karșl dahi muhafaza edeceği insanlık haysiyetidir; hürriyet insanın cisminin, ruhunun ve mallarınin korunacak imtiyazlarıdir. Binaenaleyh otorite kamunun dün de bugün de «en yüksek șey adalettir ve ada- 
letten daha yüksek birşey yoktur» düstûrunda farikasını tayin eylemek isteyen rejimin zihniyet çerçevesi içinen taşmamalrdır; yoksa yatağından tașan su gibi yalnız boğar ve yıkar: sefaletle savașacağı yerde, sefaleti arttırır. Osmanlı devletinin yıkılışı sırrını otoriteyi anlayıș ve tatbik edișinde aramak bizi müsbet neticelere vardırabilir. Tarihin kendisini, büyük ve acı bir ameliyatı yapmağa memur kıldığı Sultan Mahmut, tanzimat harekâtına: yani otoriteyi yatağında, bereketler yaratacak bir halde tutacak teșkilâtlar vücude getirmek hareketlerine imkân verecek sahayı hazırlayabilmek için savaşın gerektirdiği merkeziyetçiliği daha kuvvetlendiriyor ve eyaletlerdeki ayanları birer birer yokediyordu. Mahmut'un devrinden evvelki yakın devirlerin zaafı ve sefaletleri: yeniçeri askerlerinin ve Misır ordularının, Yunan isyanının memleket göklerinde kopardıkları boralar, hatta Alemdar'in Istanbul üzerine yürüyüșü merkeziyetçiliği kuvvetleștiren âmillerd̄en idi. İdarenin zaafı ve isyanların çıkması, kudretin bir elde temerküzünü mutlaka intaç eyliyen ve buhranlı devirlerde idarenin yüklendiği kahramanlığın ifadesi olan dikatörlüğü kaçınılması mümkün olmıyan bir zaruret kılan hallerdendir. Milletler daima hakim olan kuvvetin himaye ve idaresini ararlar. Milletlerdeki bu sevk ve idare ihtiyacı ve iyi bir idarenin șerefi olan intizam görmek arzusu, onlara hürriyetlerinden daha kıymetli gelir ve bu hal iyi bir idarenin mutlakiyet ile dahi uyuşabileceğini gösterir. Fena bir idarenin suiistimalleri devlet idaresini bir göz boyama, bir göz dağı, mevzuatını da kulak asılmıyacak bir yalan haline getirir. İdarenin zaafı, halkı «Devlet yasağ üç günden fazla sürmez» itikadına sürükler. Insanları birbirine bağlıyan ve kaynașitıran müsavat ve adalet bağları yalnız kendiliğinden çözülmekle kalmaz, hem de koparılır ve dağlar vahși bir büyüklük taşıyan «kör oğlu»larla dolar. Korkunç gecelere tahałmmül göstermiyen millet korkunç bir yumruğun sahibi olan ve intizamı iade edebilecek bulunan kuvvetli bir elin himayesi altına girer; istibdat ve merkeziyetçilik doğar, idarede hürriyete yer kalmaz.

Bu bize millî mücadeleden doğan hükümetimizin ișe, korkunç buhranların doğurduğu șekaveti (eșkiyalığı) temizlemekle başlamıș bulunmasının sebebini anlatır; ve dış düşmanla iç düşman sırasında fark olmadığını gösterir:

«Şaki oldukları İçișleri Bakanlığınca ilân olunan kişilerin verilmiș mehilin bitmesinden sonra ve hükümetçe tutulmalarından evvel her kim tarafından olursa olsun yaralanmaları ve öldürülmeleri suç sayılmaz. Yaraliyanlar ve öldürenler hakkında takibat dahi yapılmaz.» Birinci maddesini naklettiğim 356 sayılı «İalei Şekavet» kanunu millete, onun emniyet ve güvenini teker teker veya toplu olarak tehdit eden șakilere 
karşı geniş bir meșru müdafaa hảkkı tanıyor. Idatreye de cevherini ve mahiyetini teșkil eden (kuran) şuurlu bir enerji veriyordu.

Fatih'in babası II Murad'1 taht ve saltanattan bezdiren yenilmesi: Yanko Hünyadın tertiplediği haçlılar tarafından yenilmesi ona millî hudutları aşan ordulara karșı, Türk millî hudutlarını așacak ordular ve kaynaklar tedarik etmek ihtiyacını duyuyordu. Bunun neticesi olarak devleti, islâm ittihadını aramağa ve tahtı hilâfet ile birleştirmeğe süruikledi. Hilâfetin ve islâm memleketlerinin Osmanlılar eline düșmesi Osmanlı devletini büyük islâm âlemi içinde büyük bir islâm âlemi kıldı. İan'ın düşmanlığı ve itizali, Cezayir'in kayıbı, Mısır'ın ve Arap âleminin isyanı Osmanlı devletinin, bir üs olarak kullandığı islâm âlemini elinden çıkartıyor ve içinde yabancı bir cisim gibi yașadığı Avrupa'nın düșmanlığı önünde yapayalnız ve perişan bırakıyordu. İslâm âleminin içinden atılmıș memleketi, üssüz ve dostsuz bırakmamak için tanzimat hareketi onu Avrupa ile birleştirmeğe ve kaynaştırmaya uğraştı. Bunun için de Türkiyemize, Avrupaya yeni nizamin vermiș olan 1789 un lâyik ve insani zihniyetini ve o zihniyetin ifadesi olan teşkilâtını vermeğe çalıștı.

Tanzimat hareketi, islâm memleketlerinin kaybı ve islâm milletlerinin hainlikleri yüzünden içi boşalmış bir kalıp ve șekilden ibaret kalan hilâfet müessesesinin iflâsından doğmuștur. İskeletlerin mukavemeti büyük olur ve uzun sürer. Hilâfet müessesesinin mukavemeti de çok sürdü ve o iskeleti çok kiși hayata sahip sandı. Yeniçeri ordusunun Süleyman'ın cesedini canlı sanmış oldukları gibi... hilâfet müessesesinin uzuvları olan meşihat da medrese ve mahkemeleri ile mukavemette devam eyledi. Yeniçeri ocağını yokeden kuvvet bu iskeletlerin mukevemetini kıramıyordu.

Milletlerin düşman milletlerden ilk alacakları teşkilât askerî teşkilâttır. Çünki Çatalca'da durmanın veya durmamanın Sakarya'da durmanın veya durmamanın derhal vereceği sonuç var kalmak veya yok olmak șıklarından biridir. Bu kadar korkunç bir sonuç ile karşılaşan milletler düşmanlarından ilk olarak var kalabilmelerinin bağh bulunduğu askerî teșkilâtı almak zorunda kalırlar. Fakat bir vatandașın haksız yere hüküm yemesi veya idare tarafından bir haksızlığa maruz birakılması memleketi yavaş yavaş felâketine sürükler ise de onu derhal varlıkla yokluk hali arasında bulundurmaz, bu sebepten iskelet müesseselerin de mukavemet kudreti kurlamaz.

İslâm âleminin ifadesi ve islâm tarihinin muhteșem bir babı olan Osmanlı devleti halkını islâm olan ve olmayana ayırıyor, islâm olmayanı devlet dıșında bırakıyor, islâm tarihini, tarihine bir bașlangıç kılıyordu. Avrupa âleminin ifadesi ve Avrupa tarihinin bir faslı olmak iddiasını güden tanzimat Avrupa tarihinin dayanağı olan tarihi, tarihine başlan- 
gıç kılmak istiyordu. Artık halk arasındaki din farkı hukuken kalkıyor, devlet dıșındakiler de âmme haklarına malik kılınıyor ve cümlesi tebaa namı altına birleștiriliyordu. 1789 dan kaynlyan fikirler otoriteye oldugu kadar hürriyete de yer veriyordu. Otoritesiz bir idare olamıyacağ1 gibi hürriyetsiz bir itaat da olamaz. Itaat ve hürriyet birbirini tamamlayan ve sinırlandıran iki kavramdır. Ne hürriyetsiz itaat ne de itaatsiz hürriyet olabilir. Anayasa hukukunun en mühim meselellerinden biri olan otorite ile hürriyetin birleştirilmesini Napoleon idarede, idareyi yürütücü ve görüșen olmak üzere ikiye ayurmak suretile temin edilebilmiști.

Tartışma ve görüșme salâhiyeti demek olan hürriyeti, seçimden doğan meclisler ifade eyliyecek, otoriteyi tek kişiden ibaret olan yürütme uzvu temsil edecekti. Napoleon idarî görevleri yalnız görüsșen ve yürüten idare kısımlarına ayırmamıștır bu kısımlara yargılayan idare olmak üzere üçüncü bir parça daha ilâve eylemiști. İdarî görevleri arzeylediğim șekilde üç parçaya ayırmakdan, idare arasındaki bu görev bölümü tarzindan daha sade ve daha isabetli bir düșünce olamazd1.

Insanlara itikat ve âdetlerini, zihniyetlerini değiştirmek, yaktıklarına taptırmak, taptıklarını yaktırmak kolay bir dava değildir. Modern. bir Eflâtun olan Jaures bir gece Paris sokaklarında gezerken bir nevi «içtimấ korku»ile titremiș olduğunu anlatır. Insanların kalplerinden zincire vurulmuş olduğunu söyliyen bu büyük deha, Paris șehrinin bütün tașlamnı: evlerini ve anıtlamnı yapan bütün taşlarını iki avuç içine alıp onlarla yeni bir șehir kurma hevesinin, o taşların barındirdığı insanların âdelerini ve zihniyetlerini değiștirmek arzusundan daha az delice bir fikir olduğunu o gece anlamış ve titremiş bulunduğunu itiraf eyler. Islâmın kendisine «sanayi hüda» vasfı verilen peygamberini de gayesindeki azamet ilk adımını atarken derin bir ürperme ile titremis ve yere yatırıp üstünü örtmüștü. Koca Reșit Pașa da Gülhane hattını uçuk bir renk ve evine dönüp dönmiyeceğinden șüphe veren bir endișe ile okumuştu. Peygamber de Jaures te koca Reșit de zincirlerini ve tasmalarinı kalplerinde taşıyan insanların imkânsız ve hayal dedikleri ve teșebbüsünü alçakça bir düșmanlık ile karşılladıkları muazzam eserlerine yılmadan atıldılar. Aziz vatanımızin tanzimattan beri gelen tarihi, tanzimatın yenmiye uğraștığı irticaın sebep olduğu acıklı ve kanlı olaylardan örülmüștür. Halkın itiyatlarına ve hayatına girmiyen hareketler hakkında söylenecek her sözün boș, yapilacak her nazariyenin neticesiz kalması mahkûmdur. Devletin hayatının mesuliyetini tașiyan yüksek idare makamlarının zaruretini sezdikleri tanzimat hareketinin, halkın itiyadına yabancı olması tarihimizin faciasını vücuda getiriyordu. Devleti 
eline ordusuz ve idaresiz almiş olan ve memleketi iç. ve dıs politika,larını gerçekleștirecek vasitadan mahrum bir halde bulan tanzimatçılari tenkit etmek ve aleyhlerinde bulunmak kolaydır. Güç olan son dinî, içtimaî hareketlerin sükûna kavuşacaklam son konak sanan ve böylece hayat,, hareketsiz bir denizin üzerinde hareketsiz dar bir sala döndürülmüș vațana, onu Mustafa Kemal Türkiyesine vardıracak bir hareket verdirebilmektedir. Bizleri hayran bırakması lâzım gelen bu muvłffakiyet ve kudret Mustafa Kemal'in bașlangıcı olan Mustafa Reșid'e karșı da, birincisine karşi beslediğimiz minnet ve hürmetin eși minnet ve hürmeti beslemeğe mecbur kılar. Mustafa Kemal Türk Cumhuriyetinin doğumu ise Mustafa Resit onun ana karnına düşmesidir: Müesseşeler arasında da nesep rabitası vardır. Bundan bașka insan, kendi tarihinin bütün hareketleri ile mütesanit olmaya mecburdur. $\mathrm{Bu}$ hareketlerin hepsine, hadiseselere zarurî çözüm tarzlamnı vermeğe uğraşmiș gayretlerin vratanın faydasından ilham alan düşünceleri kaynak olmuștur.

Tanzimat hareketinin muvaffak olması şerefi, yoktan var : klarak kurduğu idareye ait olduğu gibi muvaffakiyetsizliğinin mesuliyeti de ayni idareye racidir. Idare prensipleri herhangi bir felsefî prensipten daha güç olarak kurulur ve çok daha güç olarak kabul ettirilir: Bir kanunun mahza Avrupa'da muvaffak olmus bulunmasi Türkiyemizde de muvaffak olacağını asla temin edemezdi. Bahusus ki devletin geleneklerine, âdetlerine ve itikatlarna yabancı olan bir nizam henüz bizim tecrübemiz imtihanından geçmemişti. Yalnız Avrupa'da tecrübe imtihanından geçmiş, ilim ve fenne uygun telâkki edilmiş bir idare tatrzını o zamanki Türkiye'ye kabul ettirmek, lâzım olởuğu kadär da güçtü. En güzel en iyi kanunlarnn kiymetleri o kanunlar tatbik edeceklerin kiymetlerine tâbidir. Kanunlar bereketli topraklara benzerler ve verimleri sapanın demirinin: yani zekâ ve ilmin ișlemdè gösterdiği gayłretle orantılı (mütenasip) olur. Kanunlar mesut sonuçlarıni tatbiklerinde gösterilen sadakat, gayret ve sebata göre verirler. Yeniliğ́n ifadesi oblan her daire, tanzimat; teșkilâtını ve zihniyetini tatbik edecek kimsélerin, yeni memurlarinnı ilmî kıymetlerini arțtıracak yüksek mektepler açtı. Mülkiye, hukuk ve diğer yuiksek mektepler bu ihtiyaçtan doğdu. "Zaten içtimaî terakkiler fikri terakkilerle birlikte yürüyebilir. Burada büytik Atatürk'ün Ankara Hukuk Fakültesini açarken söylemíș oldugù büyük nutku aynen tekrar etmek isterdim; onun yalniz son cümlesiñi kayđeylemekle iktifa edeceğim:

«Cumhuriyetin müeyyidesi olacak bu büyük müessesenin küșadında hissettiğim saadeti hic bir teșebbüste duymađm.». Tanzimatru kurduğu

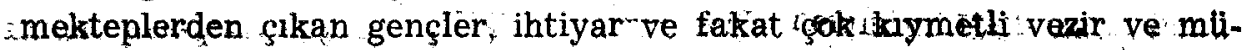


șirlerin otoriteleri altında memleketin, harplerin ve isyanların zelzelelerine rağmen bir intizam havası içinde eski nizamdan yeni tanzimata geçmesine ve tanzimat fikrinin nazarî kalmamasına imkân hazırladılar. $\mathrm{Bu}$ da gösteriyor ki idare dairelerden yani kadrodan ibaret değildir, insanlardan ibarettir. Bu sebepten idarede moral âmillerinin tesiri büyüktür: Bir idarenin erki ve başarısı memurlarının ferdî kıymetlerine dayąnır. Tanzimat hareketi gibi büyük ve güç içtimaî hadisenin tetkiki münevverler ve devlet adamları için borçtur. Cumhuriyetimizi tanzimata vücut veren zaruretler meydana getirmiștir. Sultan Mahmut eyaletlerdeki âyan ve ağaları öldürtmek suretile yeni idareyi resim halinde kurmağa muvaffak. oldu. Fakat ağalığı büsbütün kaldıramamıș ve ağa ile kendisinin bağlıları (uyrukları) arasında hiç bir kademe (basamak) kabul etmiyen ve bir kısım insanları bazı kişilere karșı tam bir uyrukluk ile bağlıyan aşiret zihniyeti bazı yerlerde devam edegelmiștir. İdare mefhumu ile telif kabul etmiyen bu halin devamina müsaade edemiyecek olan cumhuriyet, devlete karșı mahallî bir nüfuz ve kudret iddia edebilecek olan ağalığı ve şeyhliğgi kökünden söküp attı. İdareyi tekemmül ettirdi.

Tañzimat zihniyetini memlekete yayanlar en mütevazi basamağı ișgal eden idare memurları olmuştu. Zaten 'gerçekten faydalı olan kimseleri mütevazi çalışma sarfedenler arasında aramak lâzımdır. Medrese tedrisatını devam ettiren mekteplerden ziyade idare, Türkiyemize, tanzimatın istediği şekil ve kılığı vermeğe, vatanımızı tanzimatın istediğgi şekilde yürütmeğe muvaffak olmuștur. Devletin tanzimattan beri geçirdiği korkunç frrtınalara mukavemetini, tanzimatın kurduğu idare temin eylemiştir.

Devletin Mondoros mütarekesi ile çökmesinin bile yıkamadığı idarenin ekseni (mihveri) idarenin görüșen, yürüten, yargılayan kısımlara ayrilmıs bulunmasıdir. Tanzimat; Meşrutiyet ve Cumhuriyet idaresi birliğini bu eksenin etrafında toplanmıș olmasından alır. Birinci ve ikinci tertip düsturlarla üçüncü tertip düsturu bu mihver birbirinin zeyli kllar. Düsturları da ifadeleri ve aynaları oldukları rejimleri de birbirine pensibi değișmemiș iòare bağlar. Vatanda vahdet ve devamı sülâle ve hanedan değil, fakalt idare vücude getirir veya ayırır. İdarenin ayırmıș olduğu tanzimattan evvelki devlet ile tanzimattan sonraki devletin sülâle vahdeti karșisında bile eșitliğini kim iddia edebilir.

Tanzimat, merkezi idare ile mahalli idareyi birbirinden ayıran Avrupa prensibini yani, vazife tefrikini "görev ayırımını" kabul eyliyordu. 1286 tarihli, iller (vilâyet) nizamnamesi mahalli idareyi «vilâyetin umuru 
hususiyesi» tâbiri altında ifade eylemekte ve bugün dahi mahalli idareye hususi (özlel) idare adı verilmektedir.

«Meclisi umumi vilâyet» görișen idareyi, vali yürüten idareyi; idare meclisleri veya bugünkü adları ile idare kurulları idare davalarını yargılayan idareyi teşkil eder. Valì ve salâhiyetleri otorite prensibinin, umumî meclislerin salâhiyetleri hürriyet prensibinin tatbikidir. Hürriyet prensibinin tatbik sekli hakkında bir şey söylemeden evvel ön söz nevinden olmak üzere Osmanlı devleti halkının bağlı tutulmuş bulunduğu taksimden bahsedeyim. Roma halkını «Patrici» ve "Plebs» diye ikiye ayıran din, Osmanlı halkını da islâm olanlarla olmıyanlara ayınyordu. Her iki imparatorlukta da mülkî görevlerle dinî görevlerin birleșmiș olmasından doğan bu ayrma dinî görevleri görmeğe ehliyetsiz olanları mülkî görevleri de görmiye ehliyetsiz kilıyordu. Cemaatin önüne geçip te imamlık edemiyen (ibadete başkanlık edemiyen) kadın kişiler ve dinsiz kimseler halkın başına yani devletin başına geçip imam (Magister Populi) yani devlet reisi olamazdı. Müslümanların imamı (imamülmüslimin), · müminlerin emiri olacak kimsenin müslüman olması kadar tabiî ve erkek bulunması kad or zarurî bir șey olamazdı. Plebs müsbet bir tarzda tarif edilmez, ancak Patrici olmlyanlar demek suretiyle menfi bir tarzda anlatılabilir. Zimmi ve raayalar da müsbet bir tarzda tarif olunamazlar, olanlar da islâm olmiyanlar demek suretile menfi bir tarife tâbi tutulabilirler. Çünkü bunlarn kimisi müsteğmenler gibi dıșarıdan gelmedir. Kimisi yenilmiș millet fertleridir. İslâmların arasında bulunması lâzım olmayan ırk birliğinin bunların arasında da bulunmasına lüzum yoktu. Kaldı ki Ortodoks Türk adını alanlar ve ilk devșirmelerin kaynağını teşkil eden zimmiler Anadolu'daki islâm hemșerileriyle aynı ırktan idiler.

Kendilerinde tıpkı gayri müslimlerde olduğu gibi dua etmek, kurban kesmek ehliyeti bulunmayan plebs'ler așiretler ittihadı olan Roma devletinin görevlerine bir aşirete (Gentese) ve dinine intisap ile ehil olabilirlerdi. Bu dinsizler, devlet vazifelerine ehliyet veren dinî vazifelere ehliyetli Patrici kızlarla evlenebilmek salâhiyetini elde edebilmek için tam iki asır savaștılar. Bir türbe veya mihrap önünde islâm dini dairesinde dua etmek veya kurban kesmek, namaza riyaset etmek salâhiyetlerini haiz olmayan gayri müslimler binnetice mülkî görevlere getirilemezlerdi. Devletin dışinda bırakılan bu kimseler yalnız cami kapısindan girilebilen devlete girebilmek için islâm olmak zaruretindeydiler. Plebsler siyasî kadrolarını savașlar arasında teşkil eylediler; siyasî șeflerine savaş neticesi nail olabildiler. Gayri müslimler ise «Tribun»larına savașlarından evvel nail olmușlar ve dinî șeflerinde siyasî șeflerini yani «tribun» larını, dinî kadrolarında siyasî kadrolarını bulmușlardı, Lâyikliği kabul 
edemiyen, her irk ve dinden olan insanların her irk ve dinden olan kadinlarla evlenebileceğini iddia eden mèdenî kanunu kabul edemiyen tanzimat islâm olmayanları islâmlarla birleștirebilecek çareyi bulamadı ve Osmanlı devletinin yıkılması mesuliyeti idarenin üstüne yıkıldı. Çünkü idare millî mukadderatın elverișli âleti haline sokulamadı.

Vilâyet nizamnamesinin 25 inci maddesi vilâyette iki müslim ve iki gayrimüslim olmak üzere her sancaktan seçilecek ve gönderilecek üyeden mürekkep bir «meclisi umumî̀ kurar. İşbu meclisin başkanlığını valiye ve ikinci bașkanlığını da üyelerden birine bırakmayıp memurlardan valinin tayin edeceği zata bırakır. 26 nc1 maddesinde meclisin toplanma yerini ve toplanma müddetini tayin eder. Toplanma yeri vilâyetin merkezidir. Toplanma müddeti senede bir defa olmak üzere en çok 40 gündür.

Birbirlerinden ayrılmak isteyen islâmlarla islâm olmayanların karşi karşıya gelip görüșmeleri ve tartışmaları, yabancı entrikalarına âlet olan gayrimüslimlerle yurdu korumak isteyen müslimlerin birbirleriyle konușmaları merkezi ürkütüyordu. Bunun içindir ki bu birbirine düșman vatandaşların, aralar̀inda konușabilecekleri hususları kanun sıkı bir denetlemeye bağliyordu: «Her sancaktan gelecek memurlar (üyeler) ol sancağın umumen ve her kazanın hususen arzedecekleri müstediyatı yilâyet meclisine tebliğe memur olup tebliğatlarını yapmalan evvel valiye arz ile herhangi maddenin mecliste görüșmesini vali emrederse anın görüșme mevkiine konulması lâzım geleceği gibi menafii umumiyeyi vilâyete ait olup vali tarafından doğrudan doğruya ortaya konulan maddeler görüsüülür. Umumî meclis yalnız oy beyanına memur olup bunun yürütülmesi hükümeti seniyeye ait olduğuna meclisi umuminin görüşmesine memur olduğu hususların kararını mutazammın olan mazbatalar vali tarafından hükümet merkezine arz ve tebliğ olunup müteallik buyurulacak emir ve iradei seniye üzerine yürütme mevkiine konulacaktır.» (Vilâyet nizamnamesi madde 28).

Hürriyet prensibi son haddine indiriliyor, merkeziyetçilik son haddine çıkarılıyordu. Merkeziyetçiliğin son haddine vardırılması memleketi Istanbul yani merkez ve tașra olmak üzere iki zit parçaya ayırıyordu. Merkeziyetçilik Osmanlı imparatorluğu için, onun hayat ve nüfuzu için lâzımdı; içtimaî hayatın muhafazası ve memleketin tamamı mülkiyeti için lâzımdı. Fakat bu kadar kuvvetli bir merkeziyetçilik memleketi, felâketlerine sebebolan istibdada kolayca vardırdı ve temsilî bir hükümetin kurulabilmesine imkân vermedi. Tedavi hastalıktan ziyade öldürïicï oldu.

Roma'yı patrici ve plebs'lerin birleșmeleri büyütüyor. Osmanlı im- 
paratorluğunu ise islâm olanłarla olmıyanların ayrılmaları mahvediyordu. Meşrutiyet, hürriyet prensibini genişletiyor, temsilî hükümeti kuruyor ve umumî meclislere tanzimatın verememiş olduğu salâhiyetleri veriyordu. Görev ayrum prensibi, mahallî menfaatlarm tanzimini, o menfaatlarin münhasıran kendilerini alâkadar kıldığ eylemekten ibarettir. Merkez yalnız adlî, askerî ve hazineye ait malî maddelerin tanzimini kendisine hasreyler.

Ankara'da bìr Büyük Millet Meclisi ile doğan millî hükü̈metimiz lâyikliği esas olarak kabul ediyor ve anayasasında «Türkiye'de din ve rrk ayırdedilmeksizin vatandaşhk bakımından herkese (Türk) denir» prensibini ilân ediyor. Eski idarelerin ve mutlak surette idarenin muvaffak olamaldığ tevhidi' anasır, ahali mübadelesi yolu ile temin ediyordu. Hürriyet prensibine sadık olan Cumhuriyet idáresi mahallî idare ìle merkezî idareyi birbirinden ayırmayı esaslı bir idarî prensip olarak muhafaza eýliyor, fakkat hususî bütçelerin geçirđiği malî buhranlar vilâyetlere ve belediyelere maarif, sihhiye ve nafia islerinde tam bir serbesti alabilmelerine mani oluyordu. Bu da binnetice vilâyetler ahalisinin fikrî faaliyetlerinin, kamu ișleriyle uğrașmak zevklerinin inkișafına ve politik âdetlérin yerleşmesine imkân verdirmiyordu. Bir milletin politik fazilete ulașab1lmesi için uzun zamandanberi hür bulunması lâzımđır derler. Vatanımıza geçirdiği korkunç buhranlar arasında kuvvet kaynağı olmuş merkeziyetçilik ve otorite prensiplerine ifratla bağlanıșımız, denebilir ki ayni zamanda vatanı solduran öldürücü bir zehir olmuştur. Politikada her șey ölęüyui bulmaktan ibarettir. Ölçüyü kaybeden bir otoriteye Napoleon'ưn âkıbeti mukadderdir. En parlak yenmeler ile en korkunç yenifmeler arasindaki yol bazan kisa bazan uzun sürer; fakat daima parlak başlayan sırf otorite veya diğer adi ile istibdat ergeç karanlık uçurumlarda biter: Türk milletinin iki asırlik korkunç felâketlerini yenen ve Türk milletine korkunç hezimetlerỉnden tesellisini veren cumhuriyet, Türkiye Büyük Millet Meclisinden yani hürriyet prensibinden doğdu. $\mathrm{Ne}$ yałzık ki :bütün köy, kasaba ve șehirlérimizin mektep yapmak, yol yamak; su getirmek; doktor bulmak için mütemadiyen merkezin kapılarını çàlmaları mahallî idarelerin başlica zaafını teşkil ediyor ve merkeziyetçilliğin artmasına ve devamina sebeboluyor. Bu hal bize «belediyelere șehirlerin tanzim ve tesisi işlerinde yapacakları esaslı âmme-hizmetleri için muhtaç oldukları parayı» temin etmek üzere bașlamış ve 4759 sayılı kanun ile «șehir, kasaba ve köylerin kuruluș ve imarı yolundaki plân ve programlarının gerçekleștirilmesini desteklemek amaciyle bunlara kredi sağlamak» görevini üstüne alṃıș ve «Belediyeler Bankası» olan adını yeni görevinin ifadesi olan «tller Bankası»na çevirmiş olan kurul 
cumhuriyetin meskiür eserleri ve kurucusunun da Ziraat Bankasını kuran Mithat Paşa gibi meşhur simaları arasinda yer alacağını anlatır.

1789 dan itibaren mer'i olmağa bașlamış nizam, bizde tanzimat hareketine vücut verir ve islâm olanlarla olmıyanları birbirine kaynaştırmaya uğraştırırken, Avrupa'da Marks'ın meydana çıkarttığı fikirler halkı burjuva ve poletarya olmak üzere iki amansız düșman sınıfa ayırıyordu. $\mathrm{Bu}$ iki sınıfın birleșmemesi hükümeti bưjuva diktatörlüğü altına koyuyor ve poletaryayı eski plebsler gibi hükümet dișında tutuyordu. Devlet görevlerinin dıșında bırakılan proletarya için ya baş kesmek (inkiyat etmek) veya ayaklanmak șıklarından birini tercih kaliyordu. Marks ayaklanmayı tavsiye ediyordu. Burjuva ile proletarya farkını ilmî olarak tesbite uğrașan üniversite kürsüleri, proletarya ile burjuva arasında ilim ve servet farkından başka bir șey bulamıyor ve proletaryanın ilme ve refaha kavușmasını mümkün kılacak tedbirler üzerinde duruyor. Bugün Amerikan ve Ingiliz devletleri de ayni tedbirler üzerinde durmaktadırlar. Almanya'da azami derecede alınnuș bulunan tedbirler iki düşman sınıfı birbirine kaynaștıramadı. Isviçre ameleleri, tanzimatın meclislerini yarısı müslüman olan yarısı müslüman olmıyan üyelerden kuran tedbirini an'dıran bir tedbiri tavsiye eylemektedirler; șöyleki: Siyasî nizamın ifadesi olan parlömanın burjuva ve amelelerden kurulmasını, iktisadî nizamın ifadesi slan anonim șirketler idare meclislerinin yarısı sermayedar yarısı da ișçi mümessillerinden terekküp eylemesini istiyorlar. Ferdiyetçilikle camiacılık amansız bir surette çarpıșıyor. Bu çarpıșma haçlılar seferinin zamana uygun olarak aldiğı yeni șeklidir. Fakat bu yeni haçlılar seferi de eski haçlılar seferi gibi hasım dini kaldıramıyacaktır; fakat sehirde ve sokakta, mektepte ve spor sahasında, iște ve askerlikte beraberce geçen hayatta yeni yaşayıș tarzları ve yeni düșünüș ortaya çıkaracaktır. Kemalizm doğacak bu yeni düşünüș ve yașayıș tarzlarının aldığı ve alacağ paratorluktan esșiz acılar içinde doğmuş cumhuriyet sınıfı ihtilâflariyle parçalanmamak için daha ilk günlerinde «dahilde sulh» ve «sınıfsız bir devlet» programı ortaya attı. Bu programin harp sonu vaziyetlerine uygun bir tarzda gerçekleștirilmesi șerefi ve mesuliyeti idareye ait kalacaktır. Aziz Türkiyemizi yarınki âlemin medeniyet seviyesi üstüne çlkarmağa borçlu olan hükümetimizin, idaremizi, arzu edilen gerçekleștirmeleri bașarabilecek bir vasita haline koyması ve çıartması cidden candan istenecek bir șeydir. İdare bir büro iși değildir. Bir politikanın olușu ve gerçekleștirilmesi için yapılan bir gayrettir; çalıșmadır.

İdare tarafından vücuda getirilen zararlar acı tenkitlere ve idareye karş emniyetsizliklere sebebolur. Camiada bir huzursuzluk yaratır. Idarî 
dava mahkemelerini teșkil eden idare, huzursuzluğa nihayet verecek ve içtimaî sulhü koruyacak bir uzuvdur. İdarî mahkemeler fertlerin zararına olarak ișlenmiș haksızlıkları ve zararları izale etmek suretiyle idare adamlarının üstünde duran Danıștay onların hatalarını düzeltmek suretiyle idareyi halka sevdirir ve hükümet ile millet 'arasındal korkunç bir ihtilâfın çıkmasını önler. Haksız bir hükme bile baș eğmekte yalnız fazilet yoktur, içtimaî menfaat de vardır. Onun içindir ki anayasamızın «Mad. 54, Fik. 2» «Mahkemelerin kararlarını Türkiye Büyük Millet Meclisi ve Bakanlar Kurulu hiç bir türlü değiștiremezler, başkalayamazlar, geciktiremezler ve hükümlerinin yerine getirilmesine engel olamazlar» düsturunu devletin temeli kılmıştır. Türkiye Büyük Millet Meclisi $12 \mathrm{Ni-}$ san 1934 tarihinde «Danıștayın dava dairelerinin kazai vazife gören müstakil mahkeme sıfat ve salâhiyeti ile mücehhez bulunduğuna» karar vermiș «Karar: N. 803» ve Danıștay hükümlerinin; icrasında münakaşayı mucip olmasının önüne geçmiștir. Danıștay ve Yargıtayın kararlarını Türkiye Büyük Millet Meclisinden almacak. tefsirlerle felce ugratmak çok isabetsiz bir tedbir olsa gerektir. Meclis ve anayasanın Türk âmme haklarını koruyamadığını ve o hakları ancak Danıștayın koruyabilmekte olduğunu iddia eden profesör Aşil Mestr bu fikrini bir memlekete lâzım olan; «constitution» değil, «Institution»dır cümlesile ifade eder. Hayat daima değişen șartlarını, hukuka anayasada arzetmeyip yargıçın önünde arzeylediği gibi inkisarlarını da yargıçın önüne arzeyler. Politik teşkilâtın tereddiye uğramasısı (dejenere olmasını) ve milleti inkisara uğratmasını önliyebilecek tek çare idarî yargıdır. Danıștay idareyi teşkil eden teșkilât ve uzuvların, umumî refah âleti ve vasıtası kalmalarını temin edecek, onların kendilerine bizzat kendilerini amaç olarak alabilmelerine: milletin varlığının ve refahının üstünde bir gaye olarak alabilmelerine, ve milletin hayatından müstakil bir hayat iddia edebilmelerine engel olabilecek tek teșkilâttır. Çünkii yüksek idarî prensipleri ancak Danıştay koyabilir. Mahkeme içtihat ve kararları kanunların insanlarla teması demektir; o temasi nasafetli kılabilecek organ Danıștaydır. Osmanlı devleti teşkilâtı seyfiye, ilmiye ve kalemiye olmak üzere üç sınıfa dayattırılmıștı. Hükümet, seyfiye denilen kılıçlı sınıfın elindeydi. Başlangıçlarda gerçekten âlimlerden mürekkep olmuş bulunan ilmiye sınıfı ise askerî hayat ve nizamın önünde sivil (mülkî) hayat ve nizamı temsil ediyor ve bugünkü üniversite ile yargı erginin mecmuundan bașka Avrupa'da keşișlerin ve kilisenin teşkil eylemiș olduğu kuvveti de ifade eyliyordu; o kuvvetleri temsil ediyordu. Kalemiye kelimesi hakkında kolay bir tefsirde bulunulamaz. Seyf ve kalem (kıliç ve kalem) tâbiri "Hayf sana Sultan Selim, sat hayf-hem kalem ağlasın sana hem seyf» 
beyti ve (diinya işleri iki şeyle doner: Kalemin tathlığ ve kılıeın şiddetile) diyen Arap sözü kalem tâbirinin bürodan ve tahrirden ziyade siyaseti ifade eylediği kanaatini veriyor ve ne için o zamanın Hariciye Bakanlarına «Reisülküttap» denmiș olması sebebi üzerinde düșünmeye sevkettiriyor. İlmî sınıfın zaman ile takibettiği gaye, ifa etmesi lâzım gelen görev ve ödev olmaktan çıkıp o görev ve ödevleri yapanları yaşatmak endișesi oldu. Araplıklarını kurmak ve korumak endișesi vatanı yükseltmek ödevine üstün tutuldu; tanzimat deviresinin açlmasile faydalı olmaktan çıtığı zamandan sonra dahi var kalmak gayretine kapıldı ve bu hodbin emelini vatanın var kalmasina üstün kıld. Tanzimat ile yapılması lâzım gelen yeniliklere öyle kuvvetle karșı koydu ki yeni vaziyete intibak edemiyeceği anlașılan bu eski sınıf yerine yeni bir sinıf: yeni bir üniversite, yeni bir adliye kurmak daha elverișli görüldü. Cumhuriyetin șer'iye vekâletini kaldırması (429 sayılı kanun) șer'iye mahkemelerini (469 saylı kanun) ve medreseleri kapatması Sultan Mahmut'un yeniçeri ocaklarmı söndürmesiyle bașlayan hareketi tamamlayan ve gayesine vardıran bir harekettir. Hattâ șapka kanunu fes hareketile bașlamıș bir hareketin tamamlanmasıdır. Tekrar burada büyük Atatürk'ün 'Ankara Hukuk Fakültesini açıs nutkunu tamam olarłak nakletmek arzusunu duyuyor ve bu arzumu güçlükle yeniyorum. Türk tarihinde ilmiye sinıf ile yeniçeri ocaklarının teșkil eyledikleri acıklı misal ne Türk tarihine mahsus ne de münferit kalmaya mahkûm bir haldir. Kendi için yașamağa çalıșmak ve binaenaleyh bulunduğu hal üzere devam eylemeğe uğrașmak, değișmesine veya kaldırılmasına çabalıyan kuvvetlere karşı mutlak surette koymak inkilâpçlığın zıddı olan muhafazakârlık prensibinin köklerini ve esasını teşkil eder.

Partiler de milletle tesanüdlerini kaybedebilirler ve cok kere de kaybedip yeniçerilerin ve ilmiye sınıfının âkıbetine uğrayabilirler. Çünkü nasıl ki bir vücudun her azası heyeti umumiyenin yani vücudun bakasına çalışmakla beraber ilk iş olarak kendi bakasını idameye uğrașır ve kendisine en yakın hedef olarak kendi varlığının muhafazasını alırsa bir içtimaî heyetin organları da' yani memur sınfları, içtimaî sınıflar, partiler ve saireler de umumî heyetin refah ve saadetine doğrudan doğruya hizmet etmeyip bilvasita hizmet eylemektedirler; ve herhalde șuurlu faaliyetlerinin ilk hedefi olarak cemiyeti almayıp kendilerini almaktadırlar. Bir cemiyette ihtisas genişledikçe organlar heyeti umumiyeyi ihatada vuzuhu kaybeder ve bu da onlart, kendilerine teydi edilmiș ișin yapılmasından ziyade ișin devam ettirimesi gayretine düsüüür. Hodbin menfaatlerini içtimaî menfaatlerin üstünde tutmağa bașlamamış olan içtimaî organizmaya tâbi olmuş kusur ve fesatlarla savaşmak o organiz- 
mamn genişlemesi ve mürekkẹpleșmesi nisbetindè güç olur. Bir orgxnizma geliștiği ve mürekkep bir halde geldiği nisbette muhitteki mukavemet kudreti de artar. Cünkü organizmaya katılácak yeni elemanlar onu muhafaza edeceklerin kudretini arttırır ve onunla savaşacakların kudretini azaltır. Yeniçerilerin, ilmiye sınıfınin ve múhafazakâr kudretlerin menfaatleri bir oldugundan psikolojileri de bir ve áyni idi. Bunların ayri ayrı sınıflara ve mesleklere mensup olmalarının, devletin içindeki yerlerinin ayni olmamasının hiç bir kıymeti yoktu. Çünkü devletîn kurulları, müesseseleri hakkında ayni hissi beslerlerdi. Koca Reșit Pașaya gâvur Reșit Pașa denmesi (1), Mithat Pașa ve Hüseyin Avni Pașaya muhalefet edilmesi ve ikincisine en büyük kusur olarak cumhuriyetçilik isnat edilmiş bulunması bu iddiayı teyit eyleyen vakıalardır. Bunlar, içtimaî hayatı sevk ve idare eylemekte devam etmeği isterler. Cünkü bunlar, cemiyet tarafından arpalık, timar vè haslarla beslenmekte bulunmalarından şahsî menfaatlerini temin eden bu sevk ve idarenin devam etmesini ve hatta gittikçe genişlemesini ve șumûllenmesini isterler, ve kendilerine karși koyacak ve muvazeneyi temin eyliyecek başka içtimaî kuvvetlerin çıkmasını ve yeni partilerin kurulmasını istemezler. İnsan hissiyatının, içinde bulunduğu hal ve șartlara kolaylıkla intibak eylediği malûm bir hakikattır. Bu hakikatı Jaures'e insan kalbinden zincire vurulur sözünü söyletmiștir. Binaenaleyh bir rejime alısan insanlar bașka bir rejimi tasavvur bile edemezler. Tanzimat fikrini müdafaa eyliyen aydınlar saltanat ve hilâfet rejimini de müdafaa ediyorlar ve Hüseyin Avni Pașaya karșı muhalefetlerini paşanın cumhuriyetçi olduğu hakikatına veya iftirasına istinat ettiriyorlardı. Türk idaresinin değișmesi lüzumu sabit olduğu nisbette saltanat, hilâfet ve meșihattan ayrulmak imkânsız gözüküyordu. Yeniçerilik, saltanat, hilâfet ve meşihat müesseseleri muhite tesir eylemișler ve muhitten müteessir olmușlardır. $\mathrm{Bu}$ tesir ve teessür arasında muvazene hasıl edilemediğinden yıkılmıșlardır. Onun içindir ki siyasî tedbirleri asla askerî tedbirlerle mukayese etmemek lâzımdir. Askerî tedbirler tesirlerini derhal icra، ederler: Çatalca'da durmak veya durmamak Istanbul'u muhafaza etmek veya terkeylemek gibi bir neticeyi derhal hasil edecekti; Sakarya'da durmak veya durmamak Anadolu'yu, Ankara hükümetini kudreti altında tutmak veya

(1) Mustafa Resit Pasanın türbesi vapilırken içinde calısan bir Italyan I'stasının sapkasını asacak ver bulamamasından sandukanın fes konacak verine iliștirmis olduğunu ve ara voldan geçmekte olan bir adamın da pasanın ruhuna bir fatiha okumak ar. zusu ile türbenin önünde durmus ve bu hali görünce \&Allah Allah, sağ iken bu adama gâvur derlerdi; öldükten sonra da gâvur kalmıs» diverek Fatiha okumadan voluna devam evlemis bulunduğunu hocam Abdurrahman Şeref bey merhumdan ișitmiștim. 
tutmamak gibi bir neticeyi anında hasıl edecekti; fakat mebusan meclisini tatil etmek, Mithat Pașayı sürdürmek ve öldürtmek tesirini derhal veremezdi. Bu tedbir tesirini saltanatın ilgası ve hanedanın sürülmesi șeklinde senelerce sonra verecekti. Siyasette elde edilen muvaffakiyetler zahirî muvaffakiyelerdir. Çünkü mağlûp fikirler ordular gibi sahneyi galip silâhlarla terkederek çekilmiyor. Müesseseleri müdafaa eden fikirler ve hisler tesirlerini icra etmekte inadla devam eyliyor. Fikirler canlılar gibi hayat için savaşırlar. Bunun içindir ki siyaset ve idarede her muta (itaat edilen) olarak gözüken kuvvet mutlaka muta değildir ve her canlı gözüken müessese mutlaka canlı değildir. Bazan da Sultan Süleyman'ın yeniçeri nazarında canlı imiş gibi gözüken cesedinin halindedir.

Vasfi Raşid SEVİG 